\title{
Comparing the Concept of Scarcity: Conventional vs. Islamic Economics
}

\author{
Risa Bhinekawati \\ Sekolah Tinggi Ekonomi dan Manajemen Islam Mr Sjafruddin Prawiranegara
}

Scarcity is a central issue in economics as a social science. While conventional economics recognize both absolute and relative scarcities, Islamic economics recognize only relative scarcity and there is no absolute scarcity, because Allah provides sufficient resources for the whole world. The real problem of economy according to Islamic economics is the moral value or human behavior in managing relative scarcity to achieve welfare and justice. Human behavior can be governed when an individual is aware of his roles as a protector of earth and a servant of God in pursuing spiritual and material goals.

Keywords: Islamic economics, Maslahah, relative scarcity, Shariah absolute scarcity

\section{INTRODUCTION}

Economics deals with the problem of scarcity of limited resources like land, labor, capital, and skills, and how to utilize the limited resources to fulfill human needs and wants (Samuelson, 1980). Until recently, the conventional market system has been able to promote wealth to western economies but has failed to reduce inequalities between rich and poor countries, and among rich and poor population across the globe (Chapra, 2008). A recent report by Credit Suisse (2018) shows that 44.8\% or USD 142 trillion of global wealth is owned by 42 million or $0.8 \%$ of world adults. Furthermore, global economic development has also resulted in increasing disintegration of family and decreasing peace of mind and happiness of global population (Easterlin 2001; Blanchflower and Oswald, 2000; Diener and Oshi, 2000). Experts argue that market mechanisms which are based on the pursuit of self-interest and government intervention are not sufficient to improve such conditions (Chapra, 2008; Hausman and McPherson, 1993).

Islamic economics, which is aimed at maximizing maslahah (public interest) can provide an alternative in managing economic problem of relative scarcity of resources, as it can bridge the dichotomy of private and public interests, and between material and spiritual satisfactions (Ahmed, 2002, p.11). Islamic economics recognize the importance of efficiency and competition in allocation of resources as practiced by conventional economics, but the pursuit of self-interest in profit maximization should be managed in a way that it also promote "human brotherhood, socio-economic justice and the well-being of all through an integrated role of moral values, market mechanism, families, society, and 'good governance" (Chapra, 2008).

To contribute to the discussion on the topic of scarcity, this essay compares the concept of scarcity from the point of view of both conventional and Islamic economics. This essay finds that Islamic economics only recognizes relative scarcity; it views that human well-being should aim at both material and spiritual satisfactions; and it sees that the real problem of relative scarcity is human behavior. 


\section{SCARCITY ACCORDING TO CONVENTIONAL ECONOMICS}

Samuelson (1980) argues that scarcity is a reality as there are only a limited amount of resources, both human and non-human, that are capable of producing limited amount of economic goods to satisfy human needs and wants. Scarcity occurs because of demand-induced, supply-induced, and structural reasons (Heyne, et al. 2014). According to Heyne, et al. (2014), demand-induced scarcity is generated when there is an increase in demand while the supply remains the same which may happen due to population growth. Supply-induced scarcity happens when the supply is lower than the demand due to environmental causes like drought or land degradation. Structural scarcity occurs when the people do not have access to resources because of locations and political conflicts.

Furthermore, Daoud (2010) argues that the two concepts of scarcity - absolute and relative -are different from each other. Absolute scarcity refers to the gap between limited resources and limitless wants where there will never be enough resources to satisfy human wants regardless the advancement of technology (Kennedy, 2001). This is in line with that David Ricardo's argument about niggardliness of nature where land has limitations to be cultivated (Kurz, 2021). Absolute scarcity can also occur because of human activities like rapid birth rate which exceeds the ability of earth to produce food supply as suggested by Malthus theory, which will result in a demand-induced scarcity where the needs for food is higher than the quantity of food ((Heyne, et al. 2014; Daoud, 2010).

Relative scarcity, on the other hand, refers to the condition where people have to make choice between scarce commodities, because there are limitations of resources that are available to produce different goods and services (Samuelson, 1980). When making choices, there will be opportunity cost or alternative cost for people for the choices they make. Furthermore, people also have to let go the benefit that they may get for the choices they do not make (Stevenson and Lidberg, 2011). Hence, economic agents, including the producers, consumers, and governments have to make choices and trade off (Robbins, 2014; Daoud, 2010) to utilize the scarce resources to fulfill their needs and wants in achieving their well-being (Heyne, et al. 2014). Adam Smith as cited by Heath (2013) suggests that the maximum well-being can be achieved when people are given freedom to achieve their self-interest in satisfying their wants, not for the interest of others.

In sum, conventional economics recognizes both absolute and relative scarcities (Daoud, 2020). Scarcity occurs because of demand-induced, supply-induced, and structural reasons (Heyne, et al. 2014). Absolute scarcity happens because of the gap between limited resources and limitless wants (Kennedy, 2001), while relative scarcity occurs because economic agents (producers, consumers and governments) need to make choices and trade-off in fulfilling their needs and wants (Samuelson, 1980; Robbins, 2014; Daoud, 2010). And the maximum well-being can be pursued by people by exercising their self-interest (Heath, 2013).

\section{SCARCITY ACCORDING TO ISLAMIC ECONOMICS}

Unlike conventional economics, Islamic economics does not recognize absolute scarcity because AlQur'an stipulates that all resources owned by Allah, and He can give as He likes to whom He pleases, as written in surah Al Qamar:49: "Indeed, all things We created with predestination" (Possumah, 2020). Furthermore, Allah also sets the measure of all things (Surah Al Talaq: 3), and Allah gives provision to whom He will (Surah Al Noor: 38) (Azhar, 2018). Overall, Allah has provided the resources in absolute abundance, but Allah gives humans the unlimited wants which they need to regulate, desires that they need to moderate (Oran, 2012). such claims are supported by Al-Qur'an, such as in Surah Ibrahim: 34: "And He gives you all that you ask of Him, and if you would count the Bounty of Allah, you cannot reckon it. Surely, man is sinful, ungrateful!" (Azhar, 2018).

Accordingly, Islamic economics can be defined as a study of achieving human falah which includes honor, freedom from wants and power, and survival, by organizing resources given by Allah, on the basis of participation and cooperation (Khan, 1984). It can also be defined as the knowledge and practice of Shariah (Islamic rules) to acquire and distribute resources to meet human needs as obligations towards Allah and society (Zaman, 1984). Moreover, Arif (1985) specifically emphasizes the importance of Islamic 
man's behavior in managing the resources in achieving falah. Indeed, Islamic economics deals with human behavior in managing the balance between human wants and scarcity of resources which can be used to maximize falah or the well-being in the world and the hereafter (Zubair, 2012) and maslahah (Ahmed, 2002). To do so, an Islamic man should understand his roles as khalifah or a responsible man in charge of taking care of Allah's earth and use it to serve Allah for the benefit of humanity, as stipulated in Surah Huud:61 "And to Thamud [We sent] their brother Salih. He said, 'O my people, worship Allah; you have no deity other than Him. He has produced you from the earth and settled you in it, so ask forgiveness of Him and then repent to Him. Indeed, my Lord is near and responsive.'" (Aravik \& Zamzam, 2014). Furthermore, as a khalifah, an Islamic man bears the responsibility as an 'abdullah or a servant of Allah (Aravik \& Zamzam, 2014).

According to Ja'far As-Shadiq (702-765M) cited in Aravik \& Zamzam (2014, pp. 49-51), a person can achieve a status of "Abdullah if he has three criteria. First, he does not consider what he owns as his own property, because an 'abd or a servant does not have material things; even a servant of Allah considers that his body and soul belong to Allah. Second, he conducts his activities surrounding what is asked by Allah, and he prevents himself from doing what is forbidden by Allah. Third, he makes decisions based on Allah's permission. In other words, he always considers and attempts to connect what he does with God's blessings (Aravik \& Zamzam, 2014). As an Islamic man, a person is always aware about other people's right, as written in surah Al-Ma'arij: 24-25 and Al Dzariyat: 19 cited by Ascarya et al. (2017) that "within their own wealth, there are other people's right that should be given to the needy and to the people who have limitations in pursuing opportunities to fulfill their needs". Consequently, as a khalifah and 'abdullah, an Islamic man will ensure that the wealth will not only circulate among the rich, but also be distributed to needy people, as stipulated in surah Al-Hashr:7 (Possumah, 2020). An Islamic man, therefore, will ensure that relative scarcity can be mitigated in line with maqasid shariah as stipulated by Al Ghazali, cited by Ascarya et al. (2015). Maqasid shariah is the goal of Islamic faith, which consists of safeguarding the elements of faith, human life, intellect, lineage, and wealth of human being (Ascarya et al., 2015).

Based on the above discussion, it can be concluded that Islamic economics recognize relative scarcity as it deals with human behavior in making choices and in managing resources based on Shariah to achieve falah and maslahah both in the world and in the hereafter (Khan, 1984; Zaman, 1984; Arif, 1985; Ahmed, 2002; Zubair, 2012). The behavior of an Islamic man who acts as a khalifah and an 'abdullah is necessary to achieve falah and maslahah (Aravik \& Zamzam, 2014) in line with maqasid shariah (Ascarya et al., 2015).

\section{ANALYSIS AND CONCLUSION}

As discussed in points 2 and 3 above, there are similarities and differences on the ways by which conventional economics and Islamic economics view the concept of scarcity. This essay finds at least three main points as follows.

Firstly, conventional economics recognizes both absolute and relative scarcities (e.g. Daoud, 2010) but Islamic economics rejects the concept of absolute scarcity because Allah provides sufficient resources for humans and only accepts the concept of relative scarcity (e.g. Oran, 2012). Accordingly, similar to conventional economics, Islamic economics support that relative scarcity happens when people need to make choices and alternatives in fulfilling their needs. Islamic economics also support that trade-offs and opportunity costs that have to be borne by humans as the impact of their choices.

Secondly, conventional economics emphasizes on the material aspects of people's well-being by pursuing self-interest in satisfying their wants (Heath, 2013), with less emphasis on common interest (Chapra, 2008). On the contrary, Islamic economics view that well-being will be achieved when humans achieve both material and spiritual aspects of their needs and satisfactions (Zubair, 2012). Islamic economics does not reject the fact that individuals need to pursue their self-interest, but it has to be pursued in the context of moral values for not jeopardizing common interest (e.g. Chapra, 2008). Ibn Khaldun, as cited in Chapra (2008), argues that moral orientation, rather than material orientation, can contribute to social cohesion, sense of brotherhood, and achievement to common goals. Hence, the emphasis on moral 
values and spiritual objectives become one of main differences between conventional and Islamic economics.

Thirdly, while the conventional economics focuses on demand-induced, supply-induced, and structural reasons of scarcity (Heyne, et al. 2014) which are externally driven, Islamic economics view that human behavior is the main cause of scarcity (Arif, 1995). According to Islamic economics, scarcity happens because of human behavior that is not capable in making choices based on maqasid shariah to achieve falah and maslahah (e.g. Ahmed, 2002; Ascarya et al. 2015). Islamic economics emphasizes the importance of Islamic man's behavior in managing the resources given by Allah (Arif, 1985). This can be achieved when Muslims are aware about their roles as khalifah who is a guardian of God's property on earth, and 'abdullah who is a servant of Allah (Aravik \& Zamzam, 2014).

To conclude, scarcity is a central issue in economics as a social science. While conventional economics recognize both absolute and relative scarcities, Islamic economics recognize only relative scarcity and there is no absolute scarcity, because Allah provides sufficient resources for the whole world. The real problem of economy according to Islamic economics is the moral value or human behavior in managing relative scarcity to achieve welfare and justice. Human behavior can be governed when an individual is aware of his roles as a khalifah and 'abdullah who make sure that his actions are in line with maqasid shariah in pursuing falah and maslahah.

\section{REFERENCES}

Ahmed, H. (2002). Theoretical foundation of Islamic Economics. Jeddah: Islamic Development Bank Arafik, H., \& Zamzam, F. (2014). Filsafat Ekonomi Islam: Ikhtiar Memahami Nilai esensial Ekonomi Islam. Jakarta: Prenadamedia Group.

Arif, M. (1985). Towards a definition of islamic economics: Some scientific considerations. Journal of Research in Islamic Economics, 2(2), 95.

Ascarya, Rahmawati, S., \& Tanjung, H. (2015). Designing Holistic Financial Inclusion based on Maqasid Shahriah. Inaugural Annual Symposium on Islamic Finance 2015 "Islamic Finance: A Catalyst for Shared Prosperity”.

Ascarya, Husman, J.A., \& Suharto, U. (2017). Integrasi Keuangan Komersial dan Sosial Islam - Usulan Model. Working Paper. Jakarta: Bank Indonesia.

Azhar, M. (2018). Basic Economic Problem: Scarcity from Islamic Perspective. Public Lecture. Retrieved January 5, 2021, from https://www.youtube.com/watch?v=YIAWKwp4jpg

Blanchflower, D., \& Oswald, A. (2000). Well-being over Time in Britain and USA. NBER, Working Paper No. 7487, 2000. Retrieved December 30, 2020, from https://www.nber.org/papers/w7487

Chapra, M.U. (2008, March 16). Islamic Economics: What It Is and How It Developed. EH.Net Encyclopedia, edited by Robert Whaples. Retrieved December 30, 2020, from http://eh.net/encyclopedia/islamic-economics-what-it-is-and-how-it-developed/

Credit Suisse. (2018). The Global Wealth Pyramid: Growth with regional transformations. Retrieved January 4, 2021, from https://www.credit-suisse.com/about-us-news/en/articles/news-andexpertise/the-global-wealth-pyramid-growth-with-regional-transformations-201811.html

Daoud, A. (2010). Robbins and Malthus on scarcity, abundance, and sufficiency: The missing sociocultural element. American Journal of Economics and Sociology, 69(4), 1206-1229.

Diener E., \& Oshi, S. (2002). Money and Happiness: Income and Subjective Well-being. In E. Diener \& E. Suh (Eds.), Culture and Subjective Well-being. Cambridge, MA: MIT Press.

Hausman, D., \& McPherson, M. (1993). Taking Ethics Seriously: Economics and Contemporary Moral Philosophy. Journal of Economic Literature, 31(2), 671-731.

Heath, E. (2013). Adam Smith and self-interest. In C.J. Berry, M.P. Paganelli, \& C. Smith (Eds.), The Oxford Handbook of Adam Smith (p.241). Oxford University Press.

Heyne, P., Peter, J., \& Prychitko, D. (2014). The Economic Way of Thinking (13th Ed.). Pearson.

Khan, A.M. (1984). Islamic economics: Nature and need. Journal of Research in Islamic. 
Kurz, H.D. (2020). Career and Writings: Ricardo on Value, Distribution, and Capital Accumulation. Retrieved January 5, 2021, from https://www.encyclopedia.com/people/social-sciences-andlaw/economics-biographies/david-ricardo Encyclopedia.comCengage

Oran, A. (2012). Scarcity and the Subject Matter of Islamic Economics. Review of Islamic Economics, $1(2), 1-24$.

Possumah, B. (2020, November 19). Scarcity from Islamic Point of View. Lecture on Islamic Economics at Postgraduate Program, Tazkia Insitute, Jakarta, Indonesia.

Robbins, L. (2014) [1932]. An Essay on the Nature and Significance of Economic Science (2nd ed.). London: Macmillan.

Samuelson, P. (1980). Economics (11th ed.). New York: McGraw-Hill.

Stevenson, A., \& Lindberg, C. (2011). Opportunity cost. Oxford: Oxford University Press.

Zaman, H. (1984). Definition of Islamic economics. Journal of Research in Islamic Economics, 1(2), 95.

Zubair, H. (2012). Scarcity, self-interest and maximization from Islamic angle. Kuala Lumpur: INCEIF. 